$$
\begin{gathered}
\text { YOUTH, } \\
\text { GLOBALIZATION, } \\
\text { AND THE LAW }
\end{gathered}
$$


OROANIZED BY THE SOCIAL SCIENCE RESEARCH COUNCIL COLLABORATIVE RESEARCH NETWORK ON YOUTH AND GLOBALIZATION

SSRC 


\section{YOUTH, \\ GLOBALIZATION, AND THE LAW}

E D I T E D B Y

S U D H I R A L L A D I V E N KA T E S H A N D R O N A L D KA S S I M I R

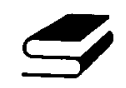


Stanford Universicy Press

Stanford, California

(C) 2007 by the Board of Trustees of the

Leland Stanford Junior University. All rights reserved.

No part of this book may be reproduced or transmitted in any form or by any means, electronic or mechanical, including photocopying and recording, or in any information storage or retrieval system without the prior written permission of Stanford University Press.

Library of Congress Cataloging-in-Publication Data

Youth, globalization, and the law / edited by Sudhir Alladi Venkatesh and Ronald Kassimir ; organized by Social Science Research Council Collaborative Research Network on Youth and Globalization.

p. cm.

Includes bibliographical references and index.

ISBN-13: 978-0-8047-5473-6 (clorh : alk. paper)

ISBN-13: 978-0-8047-5474-3 (paper: alk. paper)

1. Juvenile justice, Administration of. 2. Youth-Legal status, laws, etc. 3. Youth-Social conditions-21st century. 4. Social control.

5. Globalization - Social aspects. I. Venkatesh, Sudhir Alladi.

II. Kassimir, Ronald. III. Social Science Research Council (U.S.).

Collaborative Research Network on Youth and Globalization. HV9069.Y67 2007

$305.235-\mathrm{dc} 22 \quad 2006012938$

Typeset by BookMatters, Berkeley in 11/15 Adobe Garamond

Original Printing 2007 